\title{
A atual conjuntura do transporte público no espaço insular da região Metropolitana da Grande São Luís - Ma
}

\section{Juan Guilherme Costa Siqueira}

Graduado em Geografia, Departamento de Geociências pela Universidade Federal do Maranhão e Mestre em Desenvolvimento Socioespacial e Regional, pela Universidade Estadual do Maranhão, Brasil

http://lattes.cnpq.br/3260712369612350

\author{
Marcelino Silva Farias Filho \\ Departamento de Geociências, Mestre em agroecologia pela Universidade Estadual do \\ Maranhão, Licenciado e Bacharel em Geografia pela Universidade Federal do Maranhão, \\ Brasil \\ http://lattes.cnpq.br/9518647136368245
}

Recibido: 13 de agosto de 2019. Aceptado: 30 de junio de 2020.

\begin{abstract}
Resumo
No Brasil, a expansão urbana dispersa originou problemas na mobilidade de passageiros, no transporte de mercadorias e em muitos outros setores. $\mathrm{O}$ artigo objetivou-se analisar a mobilidade do usuário de transporte público nos municípios da Ilha do Maranhão e a sua relação entre as instituições (públicas e privadas) e equipamentos urbanos do referido setor. A pesquisa foi realizada em 2015 nos municípios assentados na Ilha do Maranhão que, juntamente com outros municípios, compõem a Região Metropolitana da Grande São Luís. Aplicou-se 203 questionários e realização de 10 entrevistas com usuários do transporte público. Ao longo da pesquisa, foi possível observar que os equipamentos urbanos dos municípios investigados são inadequados para garantir mobilidade aos usuários, a qual está concentrada nas áreas nobres. $\mathrm{O}$ transporte público perdeu produtividade ao longo dos anos, o que pode ser comprovado pela estagnação do IPK e pela migração de muitos usuários para o transporte alternativo.
\end{abstract}

Palavras-chave: Expansão urbana. Equipamentos urbanos. Mobilidade de passageiros. 


\title{
The current conjuncture of collective public transport in the insular space in the Metropolitan region of Greater São Luís-Ma
}

\begin{abstract}
In Brazil, the dispersed urban sprawl has led to problems in mobility of passengers in the transport of goods and in many other sectors. The article aimed to analyze the mobility of public transport users in the municipalities of Ilha do Maranhão and its relationship between institutions (public and private) and urban equipment in this sector. The research was conducted in 2015 in the municipalities settled on the Island of Maranhão, which, together with other municipalities, make up the Metropolitan Region of Greater São Luís. 203 questionnaires were applied and 10 interviews were conducted with users of public transport. Throughout the research, it was possible to observe that the urban equipment of the investigated municipalities is inadequate to ensure mobility to users, which is concentrated in the noble areas. The public transportation lost productivity, which can be evidenced by the stagnation of the IPK and the migration of many users for alternate transportation.
\end{abstract}

Key words: Urban sprawl. Urban equipments. Mobility.

Palabras clave: Expansión urbana. Equipamientos urbanos. Movilidad de pasajeros.

\section{Introdução}

O transporte público é um importante meio de deslocamento da população em todo o mundo. Com o incremento da urbanização no século XX, houve maior interesse em estudos sobre transportes em grandes cidades como Nova Iorque (E.U.A), Paris (França) e Londres (Inglaterra). No Brasil, na medida em que ocorreu uma acelerada expansão urbana sem a provisão de infraestruturas básicas para a acessibilidade e garantia das relações de produção, a população enfrentou dificuldades de mobilidade devido às grandes distâncias de deslocamento casa/trabalho e às péssimas infraestruturas nas suas periferias.

Segundo Maricato (2002:123), isso resultou de um "planejamento funcionalista" que atendeu à interesses neoliberais. Esse modelo de planejamento definiu as cidades brasileiras marcadas pela "modernização incompleta" e "apenas uma parte das nossas cidades" e, consequentemente, tornou-se contraditório entre a retórica e prática, pois para o pensamento neoliberal o que importou-se foram o livre mercado e o fim da burocratização, da ineficácia e do autoritarismo (Maricato, 2002).

Em relação ao planejamento urbano no Brasil, pouco foi posto em prática e desvinculou-se à gestão urbana. A continuidade do "patrimonialismo" (Maricato, 2002), a "continuidade dos privilégios senhoriais na mentalidade da formação burguesa" e "adaptação das heranças coloniais no processo de modernização" (Maricato, 2003) resultaram na segregação social pela não efetivação de políticas urbanas e distribuição de renda para as cidades com maior capital financeiro.

As obras de infraestrutura urbana alimentam loteamentos urbanos denominados de "ociosidade" (Peixoto, 2011), chamados também de "vazios intersticiais" (Cocco, 2011a). Ambos com proprietários de terra, utilizam-se da "especulação fundiária" e da "não a democratização do acesso à terra para moradia" com propósito de exclusão social pelos privilégios das classes mais favorecidas.

Ferreira (2014) comentou que, em São Luís, a efetivação do plano diretor de 1977 pouco concretizou-se no tocante ao sistema de transporte público e a efetivação de projetos, 
sendo eles: implantação de via exclusiva para ônibus nas Avenidas Daniel de La Touche e a Avenida Médici; "articulação da Avenida dos Franceses com o Anel Viário" (Centro histórico); "articulação dos bairros aos eixos viários principais"; e a urbanização dos bairros e realização de "estudos urbanísticos". Ao contrário, resultou-se na expansão urbana dispersa no Bairro Anjo da Guarda após a expulsão de "2000 famílias" que se localizavam nas palafitas e habitações insalubres do Bairro Goiabal (Ferreira, 2014). A ação higienista realizada na administração de Jayme Tavares (em 1920) preocupou-se mais com o "distanciamento da pobreza em área nobre" do que com a infraestrutura e contribuiu para a expulsão de moradores do bairro Goiabal, objetivando valorizar o centro histórico de São Luís (Farias, 2004; Ferreira, 2014).

Neste sentido, a "dinâmica espacial da segregação" é um problema evidente à medida que há um elemento de "privilégios" e de "controle da reprodução social" para a manutenção da elite na implantação de bairros de maior status (Corrêa, 1989, p. 66 e 71). Se, por um lado, a expansão é incentivada por interesses imobiliários e produz cada vez mais equipamentos urbanos seletivos, voltados para a demanda solvável, por outro a população pobre é expulsa e obrigada a ocupar "terrenos ilegais" e "Áreas de Proteção Ambiental" (Maricato, 2008:155 e 163). É o caso das Área de Proteção Ambiental do Maracanã e do Itapiracó, em São Luís (Siqueira, 2018; Ferreira, 2014).

Em São Paulo (Brasil), Barat (2001:2) afirmou que nos anos 1980 e 1990, ocorreu um amplo processo de descentralização industrial, com profundas repercussões no sistema urbano de trânsito e transporte estadual. Em consequência, buscaram-se "novas funções e especializações", o que atraiu fluxos e migrações inter-regionais de longa distância para ocupação de postos de trabalho, configurando a sua hinterlândia.

O transporte público nem sempre é o meio mais utilizado pelas pessoas, considerando diferentes grupos sociais, pois o seu uso depende dos contextos e suas determinantes econômicas, sociais, políticas e culturais, ainda que, considerando o processo de desenvolvimento econômico, o transporte público potencializa a força de trabalho e reduz os custos de circulação. No entanto, desigualdades no tempo de deslocamento são fontes de iniquidades na reprodução social dos usuários. Nesse caso, os grupos sociais mais prejudicados são os que foram expulsos da área central ou moram em áreas distantes do serviço (Cocco, 2011a), havendo vários fatores sociais e econômicos que influenciam direta ou indiretamente no deslocamento do usuário de transporte público nas cidades e que determinam as suas interações espaciais.

Como parte da existência e do processo de transformação social, as interações espaciais se caracterizam por assimetria, "por relações que tendem a favorecer um lugar em detrimento de outro ampliando as diferenças existentes, isto é, transformando os lugares" (Corrêa, 2006:280). O conceito de interações espaciais envolve a mobilidade cotidiana, a acessibilidade e a realização da atividade que demanda o fenômeno de transporte (Cocco, 2013).

Nos municípios de São Luís, São José de Ribamar, Raposa e Paço do Lumiar - que compõem a Ilha do Maranhão - bem como todos os municípios da Região Metropolitana da Grande São Luís (Figura 1), o principal meio de transporte público é o ônibus urbano, sendo que cerca de 550 mil usuários são atendidos diariamente e mais de 2 milhões de viagens são executadas diariamente (São Luís, 2020). No entanto, os usuários que o utilizam sofrem com longas distâncias de mobilidade, principalmente os residentes nos municípios supracitados. 


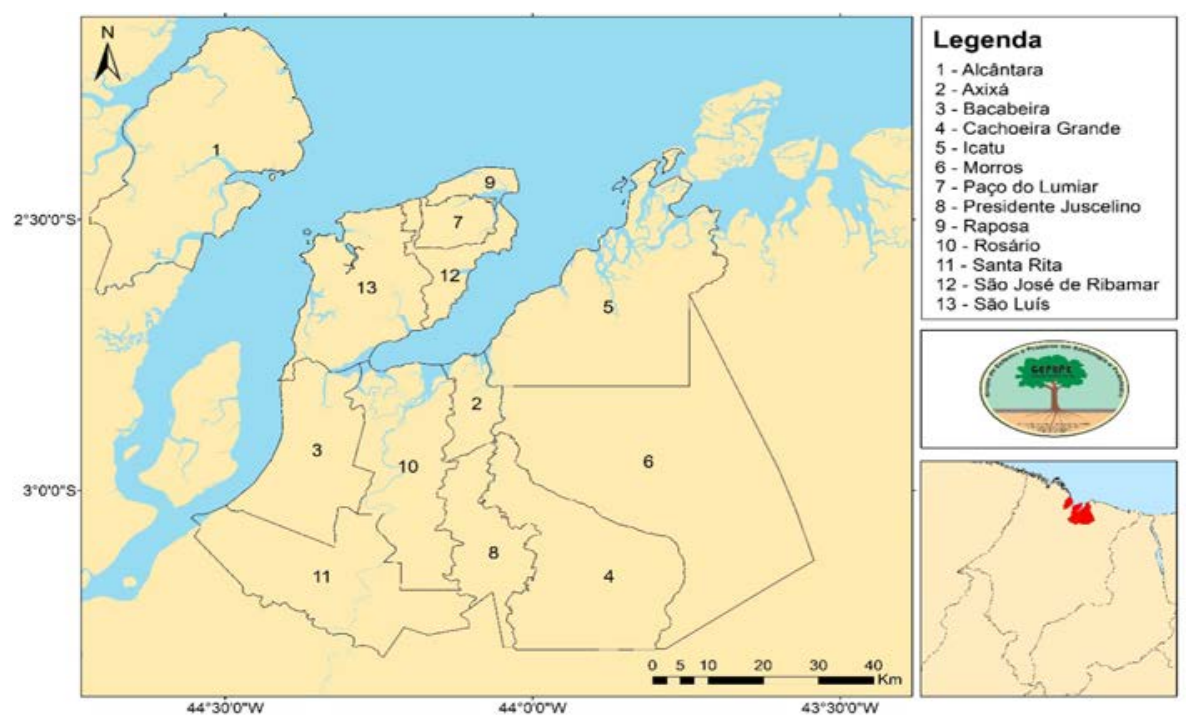

Figura 1. Municípios integrantes da Região Metropolitana da Grande São Luís. Fonte: elaborado pelo autor

Devido às dificuldades de deslocamento e pelo fato de a "dispersão urbana" (Sposito; Chatel, 2015) - urban sprawl (Karakayaci, 2016) - distribuir e espraiar a população em "zonas separadas e descontínuas no espaço" (Chatel e Sposito, 2015:122), o transporte público não conseguiu atender os usuários de maneira eficiente e em todos os lugares, aumentando distâncias de mobilidade a pé. No Bairro do Maracanã, em São Luís, o usuário caminha $1 \mathrm{~km}$ até a parada de ônibus mais próxima.

A incapacidade do transporte público em atender a demanda existente (Balassiano, 1996), os maiores headways (Cocco, 2011a) e o não interesse dos empresários em implantar novos itinerários, originaram a existência dos transportes alternativos e seu destaque nos municípios da Ilha do Maranhão.

Diante desse contexto, o presente artigo objetivou: 1) verificar os elementos de ordem histórica e política no crescimento urbano da região, a relação com os problemas de mobilidade e como estes são enfrentados pelos usuários; 2 ) compreender as razões do deslocamento com ênfase nos estudos de crescimento urbano e demandas de transporte e; 3 ) analisar dados sobre os possíveis polos geradores de mobilidade na Ilha do Maranhão, comparando com as condições de infraestrutura.

Apesar da importância da abordagem da temática do transporte público e dos entraves à mobilidade, poucas discussões têm sido aprofundadas acerca da realidade dos municípios da Ilha do Maranhão, em que o crescimento populacional, a expansão urbana dispersa e ausência de infraestruturas para oportunidades de emprego e renda nas zonas periféricas pressionaram o aumento da mobilidade com incrementos na frota de automóveis nas principais vias de São Luís, à medida que o transporte público se tornou deficitário.

\section{Metodologia}

O presente artigo foi fundamentado com base no método Materialismo Histórico e Dialético que, segundo Cheptulin (1982), permite abordar o movimento da sociedade como processo transformador. O movimento das pessoas e mercadorias constitui-se como processo fundamental de transformação que dá origem, diretamente e indiretamente, 
às interações espaciais (Corrêa, 2006), as quais impuseram mudanças, a partir dos deslocamentos efetuados através de meios de transporte (Cocco, 2011a). Com ênfase na economia urbana, os debates relacionados à política territorial (Miralles-Guasch, 2014) e sobre a evolução do espaço urbano (Corrêa,1989; 2006; Santos, 2009; Villaça, 2001) foram necessários e presentemente inseridos para que as particularidades locais fossem compreendidas.

Tratando-se da realidade da Ilha do Maranhão, alguns autores discutem a cidade e sua "modernização" nas primeiras décadas do século XX (Farias Filho, 2004), transformações e produção do espaço urbano (Ferreira, 2014), indicando problemas de mobilidade. Entretanto, há lacunas na abordagem da infraestrutura de transporte público e dos problemas de mobilidade urbana, o que justificou a realização da pesquisa que originou este artigo. Essa pesquisa está no estágio concluído e foi realizada seguindo os seguintes procedimentos metodológicos:

1) realizou-se revisão de literatura com base em monografias, dissertações e teses de doutorado e artigos científicos relacionados ao objeto de estudo sobre transporte público e mobilidade urbana;

2) fez-se levantamento documental sobre a temática, abordando:

a) concessão do serviço de transporte público coletivo de passageiros do município de São Luís de (Concorrência pública n 04/2016/CPL); Lei Estadual ${ }^{\circ}$ 9.431/2011, que dispôs sobre o sistema de transporte público coletivo rodoviário intermunicipal e semiurbano remunerado de passageiros do Estado do Maranhão; Portaria Estadual n 27/2015 - GAB/MOB que dispôs acerca da necessidade de se promover o recadastramento das empresas que operam no sistema de transporte coletivo rodoviário intermunicipal e semiurbano de passageiros do Estado do Maranhão e Portaria Estadual n 72/2015 - GAB/ MOB que dispôs acerca da criação do serviço especial no sistema de transporte coletivo rodoviário semiurbano de passageiros do estado do maranhão;

b) Jornal Diário Catarinense, terça-feira, 20 de agosto de 2013 em que foi apresentada a entrevista da Prof ${ }^{a}$ Dr. Carme Miralles-Guash e expostos debates sobre a mobilidade nas realidades sociais, econômicas, políticas e culturais, a qual a mídia e outros jornais (O imparcial, Folha de São Paulo, Estado do Maranhão) não expõem com seriedade;

c) planos diretores de 1977, 1992 e 2006 para compreender a evolução do espaço urbano na Ilha do Maranhão. Os outros municípios ainda não apresentaram seus planos diretores; Plano Diretor de Desenvolvimento Integrado da Grande São Luís em abril de 2019 para análise dos estudos realizados da Ilha do Maranhão e da Região Metropolitana da Grande São Luís;

d) Estudo de Origem-Destino feito pela Secretaria Municipal de Trânsito e Transportes de São Luís em 2001 para análise dos fluxos de transporte público, da metodologia e do público-alvo estudado;

3) analisou-se e interpretou-se o censo demográfico 2010 do Instituto Brasileiro de Geografia e Estatística sobre o tempo de deslocamento de usuários do transporte público;

4) realizaram-se duas entrevistas semiestruturadas na Agência Estadual de Transporte e Mobilidade Urbana do Maranhão (uma com o presidente e outra com a diretoria de transporte e mobilidade) para obter informações acerca da operação do sistema de transporte rodoviário intermunicipal da Ilha do Maranhão; duas semiestruturadas na Secretaria Municipal de Trânsito e Transportes de São Luís (uma para a gerência de transporte e outra para o superintendente de transporte) com isto acessou-se o relatório ao estudo de origem-destino de São Luís, em 2001 (mais recente); e uma semiestruturada com o superintendente do Sindicato das Empresas de Transporte e obteve-se a concessão das empresas do transporte púbico de São Luís e a relação dos custos de operação com a infraestrutura provida; 
5) aplicaram-se 203 questionários de origem-destino (acompanhados de 10 entrevistas semiestruturadas) com usuários de transporte público no Terminal Cohab, em São Luís, dia 17/06/2015 (09:30 às 17:30) e obtiveram-se opiniões dos usuários quanto a distribuição da frota operante do transporte público, a infraestrutura das vias urbanas e a qualidade do transporte público. Os usuários foram de baixa renda, utilizaram o transporte público como opção de deslocamento, visto que o custo da gasolina por quilômetro do automóvel é maior que o ônibus. Estes foram trabalhadores, estudantes, domésticas, professores, turistas, comerciantes e idosos;

6) elaborou-se um mapa de origem e destino de passageiros nos quatro municípios da Ilha do Maranhão (São Luís, São José de Ribamar, Raposa e Paço do Lumiar). Esse mapa representou os fluxos decorrentes da Ilha do Maranhão e relacionou a realidade do objeto de estudo com a bibliografia de Rodrigo Giraldi, Milton Santos, Carme Miralles-Guash, Roberto Lobato Corrêa e Eduardo Vasconcellos em que ambos abordaram o tema "transportes"; elaboraram-se mapas para representar os bairros e as localizações dos equipamentos urbanos.

\section{Interações espaciais na questão do transporte público}

A indefinição da legislação urbanística pelos governantes é resultante do planejamento "modernista/funcionalista" (Maricato, 2002:122). Este promoveu exclusão social, frente ao interesse do mercado imobiliário. Além disso, ocorre a "fragmentação socioespacial" devido as "descontinuidades do tecido urbano" quando desacompanhados de infraestruturas e transporte (Chatel e Sposito, 2015:127), e, por outro lado, a "expansão limitada da aglomeração" - à medida que a dispersão urbana não está contíguo entre loteamentos - marcadas por "descontinuidades territoriais" (Sposito, 2010, p. 124). Estas resultaram em ampliações do deslocamento em áreas distantes. Paralelamente à conjuntura supracitada, o aumento do número de automóveis, em prejuízo ao transporte público, levou à ocupação das vias principais pelos veículos de passeio, resultando em perdas de tempo nos congestionamentos (Cocco e Silveira, 2011b).

As vias de transportes têm enorme influência não só no arranjo interno das cidades, mas também sobre os diferenciais de expansão urbana. A capacidade das vias em integrar os diversos elementos da cidade, resulta em diversos fluxos de transporte intraurbano (Villaça, 2001).

Portanto, quando se diz, por exemplo, que uma via provoca o crescimento ou desenvolvimento urbano nesta ou naquela direção, estamos nos referindo ao arranjo espacial do crescimento, não à sua causa primeira (...) O primeiro efeito que uma via regional ou terminal de transporte urbano provoca nos terrenos adjacentes é a melhoria de sua acessibilidade e daí sua valorização (Villaça, 2001:80).

O surgimento dos povoados, de cidades, movimentação de pessoas e mercadorias originaram as demandas de redes de transportes regionais. Essas, por sua vez, exerceram grande influência e tornaram-se grandes cidades através do tempo, conjuntura em que as estradas vicinais deram origem às vias urbanas de grande circulação e as atividades incrementadas geraram novas demandas para o transporte.

Os motivos das viagens são influenciados por fatores sociais, econômicos e culturais. O trabalho e a escola assumem destaque nos deslocamentos, independentemente do local e do nível da renda da população (Vasconcellos, 2000). Por outro lado, 
o desenvolvimento do sistema de transportes e das telecomunicações acompanha a configuração territorial mediante as necessidades de circulação (Santos, 2009).

Outro problema é a carência de integração das políticas de uso do solo com o transporte público. $\mathrm{O}$ fato é que áreas de baixa densidade, fragmentadas territorialmente, pressionam a qualidade do serviço de transporte público (Cocco, 2011a) e tendem a reduzi-la. Há o aumento do número de moradias das camadas de baixa renda, mas não há crescimento e ampliação dos equipamentos urbanos nos bairros. Isso evidencia um acréscimo do tempo de deslocamento e reflete um prejuízo para a população que luta por melhores condições de habitação, trabalho, transportes, saúde e qualidade de vida e que, muitas vezes, ocupam bairros mais distantes devido à valorização imobiliária das áreas mais centrais.

Desse modo, afirma-se que as políticas públicas direcionadas a referido setor devem caminhar com objetivos prioritários de redução dos tempos de deslocamento. A proximidade da residência garante redução no uso dos meios de transporte (a pé, bicicleta, carro e ônibus) e dos quilômetros percorridos. Entretanto, isso só se consolida com a provisão de equipamentos urbanos e sociais de modo equitativo nos bairros, disponibilizados pelo Estado em suas diversas instâncias, tais como hospitais públicos, postos de saúde e escolas públicas. Assim, é necessário descentralizar os espaços urbanos, mas, ao mesmo tempo, torná-los mais compactos e diversos em usos.

\section{Transporte público e a dinâmica do espaço urbano na Região Metropolitana da Grande São Luís}

Em relação à formação socioespacial (Santos, 1977) e, especialmente, do Maranhão (Cunha, 2015; Ferreira, 2006; Trovão, 2008; Cabral, 1992) e São Luís (Ferreira, 2006; 2014; Cunha, 2015), o início deu-se em duas frentes: a frente litorânea e a frente pastoril (Cabral, 1992; Trovão, 2008). A terceira frente adveio do litoral maranhense e originou a civilização do babaçu, do arroz e do algodão até o início do século XX (Trovão, 2008), conforme a Figura 2. 


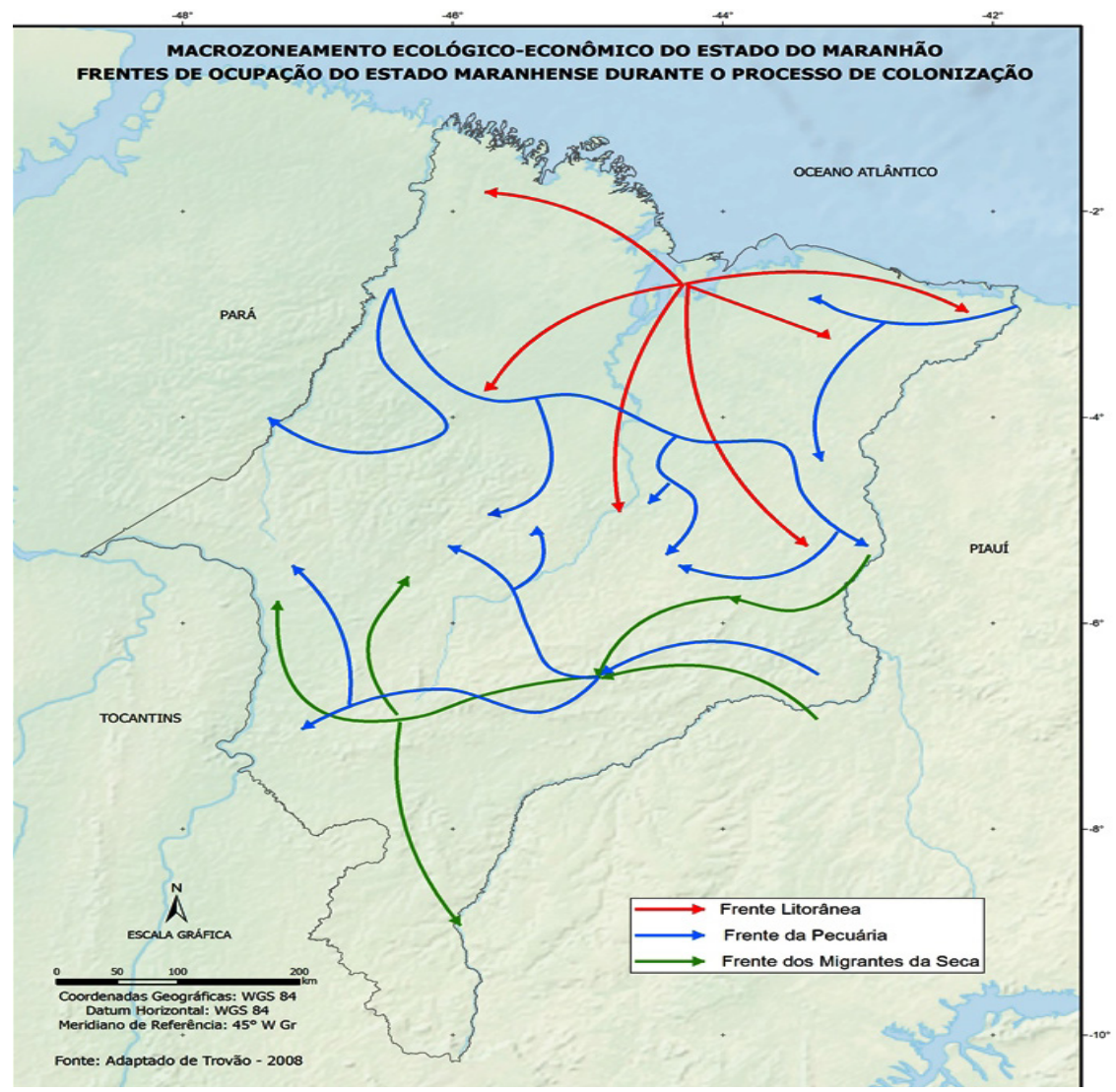

Figura 2. Frentes de ocupação do Estado do Maranhão. Fonte: Trovão, 2008.

A frente litorânea originou-se em São Luís e teve como objetivo a ocupação do espaço maranhense (Trovão, 2008). Duas ramificações desenvolveram-se em via marítima e fluvial, nas quais ocorreu a exportação de produtos agrícolas para o interior do continente. Esta ocupação resultou-se na fundação de cidades tais como Alcântara, Guimarães, Pindaré, Turiaçu e Carutapera (Trovão, 2008). Isso originou uma estrutura socioespacial baseado na agricultura, com relações de produção escravocrata (Cunha, 2015).

A frente pastoril ocorreu com base na pecuária bovina, a agroindústria açucareira e a disponibilidade de terras para ocupação (Cabral, 1992) em busca de pasto, ocupando os campos no sul do Maranhão. Essa frente foi apoiada pela iniciativa privada, oriunda da Bahia (Cabral, 1992; Trovão, 2008) onde abriram-se caminhos, devastaram-se campos, povoou-se o Rio São Francisco e ultrapassou-se o Rio Parnaíba, cuja rapidez resultou na abundância de terras. A partir de 1730, a ocupação de campos originouse genericamente de Pastos Bons (atual fundação do município). Em consequência, surgiu uma estrutura socioespacial apoiada pela pecuária e com relações sociais de cunho feudal (Cunha, 2015). Na segunda metade do século XVIII, a frente de vaqueiros atravessou o Rio Balsas e resultou na instalação de fazendas e a implantação de aldeias de São Félix de Balsas, próximo à confluência dos rios Balsas e Parnaíba, mais tarde vila e atualmente município (Cabral, 1992).

A frente da pecuária expandiu-se à medida que houve a ramificação da frente litorânea, pelas reentrâncias do mar e rios em direção ao interior, instalação de portos fluviais e exportação de produtos agrícolas (cultivados do interior do Maranhão); e da frente pastoril, com a expansão da pecuária pelos vaqueiros e criadores de gado (Trovão, 2008). 
A cidade de São Luís situa-se na porção ocidental da ilha do Maranhão, de frente para a baía de São Marços, e sua "fundação" pelos franceses remonta há 8 de setembro de 1612. Devido à posição estratégica em relação ao continente europeu e como ponto de acesso ao interior da Amazônia, a cidade de São Luís esteve ocupada, por curtos períodos, por franceses e holandeses durante o século XVII. Para o fortalecimento do poder político local, foi determinante a criação do forte, do ancoradouro e, posteriormente, do porto de embarque e desembarque dessa cidade.

Em São Luís, segundo Ferreira (2014), o crescimento urbano dividiu-se em quatro períodos, tendo em vista a formação da cidade (1612-1875); ampliação dos meios de transporte (1876-1950); expansão urbana (1951-1970); e desenvolvimento econômico (1971-atual), conforme a Figura 3.
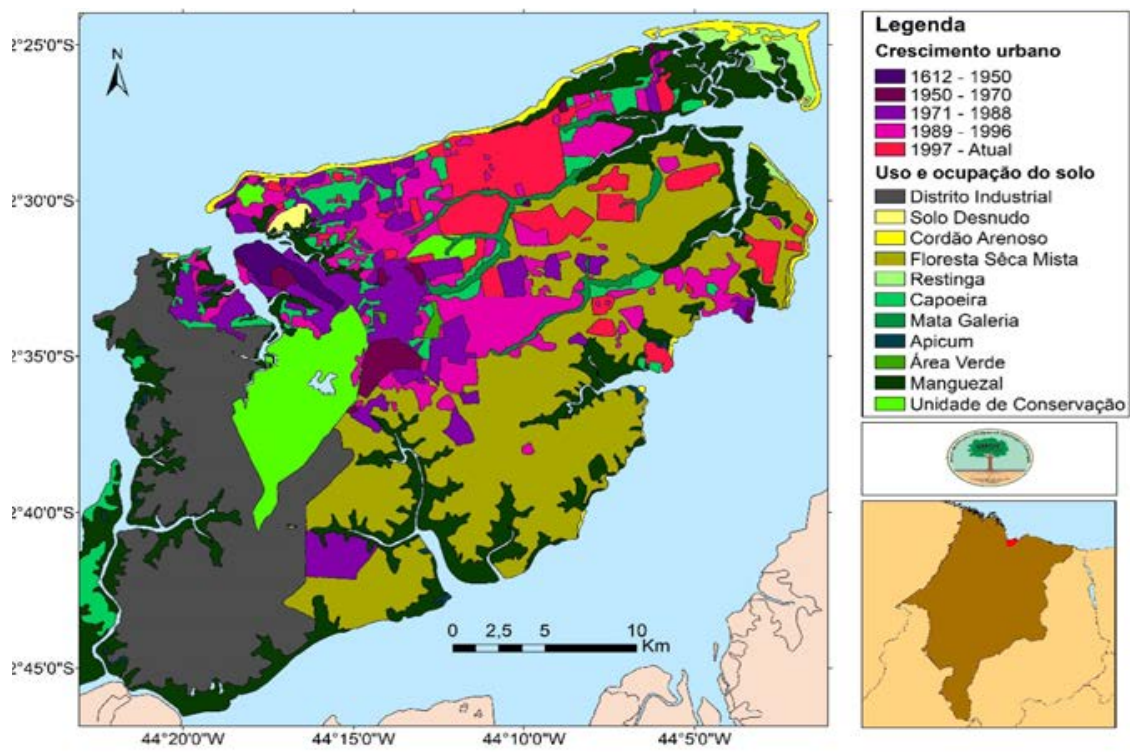

Figura 3. Crescimento urbano e uso do solo da Ilha do Maranhão. Fonte: elaborado pelo autor.

Em 1613, as tropas comandadas por Jerônimo de Albuquerque iniciaram os combates para a expulsão dos franceses, quando - após uma trégua e litígio das coroas interessadas - foi concretizada, em 1615, a tomada do forte São Luís por uma tropa portuguesa, sob comando de Alexandre de Moura (Ferreira, 2014). A alta fertilidade dos rios, o solo plano e a abundância de terras cultiváveis ajudaram no cultivo da mandioca, arroz, pesca e criação de animais (Cunha, 2015). Baseado na produção algodoeira, foi instituída, em 1755, a Companhia Geral de Comércio do Grão-Pará e Maranhão (CGGPM) pelo Reino de Portugal, a qual instalou-se em São Luís em 1758 (Ferreira, 2014).

A CGGPM adotou uma política engenhosa de preços; trouxe agricultores da Europa; estabeleceu-se créditos aos agricultores para o tráfico escravista; forneceu sementes de qualidade para o plantio de arroz e cana de açúcar; estabeleceu monopólio das transações comerciais e desenvolveu um grande mercado de mão de obra escravista vindo da África para a produção fosse exportadora, em larga escala, já que houve estabelecimento da concorrência mercantilista portuguesa da Europa, frente a supremacia do mercado da Inglaterra. Na metade do século XVII, ocorreu na mesma a revolução puritana e o consequente aumento da produção capitalista, a qual originou o império inglês em detrimento de outras colônias (Cunha, 2015). 
Diante do crescimento econômico nos municípios na Ilha do Maranhão, em especial em Raposa, Paço do Lumiar e São José de Ribamar, houve a expansão urbana dispersa, o que pode ser explicado pelo relativo isolamento desses núcleos de povoamento durante o Período Colonial. Entre 1612 a 1875, verificou-se a instalação de moradias vinculadas à dotação de infraestruturas voltadas à mão de obra com objetivo de exploração de algodão e cana de açúcar pela Coroa portuguesa. No final desse período, houve a instalação das indústrias de tecidos, que demandaram pela abertura de vias para expansão da colônia e abertura de caminhos, a exemplo do Caminho Grande (implantado em 1655) em direção à vila do Anil (Ferreira, 2014).

Em 1870, houve o emprego do bonde no momento da expansão urbana para atendimento às demandas de transporte de passageiros em São Luís, com ampliação do trajeto de deslocamento e redução do tempo e custo destinados a estas variáveis. Em 1920, a população de São Luís possuía 52.929 habitantes e isso já evidenciava problemas de transporte, saúde pública e habitação (Farias Filho, 2004). Para Cocco (2013), a conjuntura acima remonta permanências estruturais (sistema viário, padrões arquitetônicos) e superestruturais (cultura, relações sociais) que afetam a mobilidade. A título de exemplo, as vias que interligavam as principais localidades da cidade de São Luís eram a Avenida Beira-Mar (1927) e a Avenida Getúlio Vargas/ Avenida João Pessoa/ Casemiro Júnior (1970) (Farias Filho, 2004).

As ações estatais também resultaram na construção das pontes do São Francisco (1970), a Newton Belo (1969 - 1970), além da barragem do Bacanga (1970). Essas construções facilitaram a expansão para os bairros São Francisco, Anjo da Guarda, Ponta D’areia, Renascença e Olho D'água (Ferreira, 2014). O crescimento urbano desse período foi dinamizado pelo crescimento industrial, a partir da instalação da então Companhia Vale Rio Doce (atual Vale) e da Alumar (Alcoa).

A implantação de conjuntos habitacionais entre 1960 e 1986 exigiu a ampliação das vias de acesso (principalmente avenidas) e viabilização da expansão urbana (Ferreira, 2014). Essas demandas foram registradas no Plano Diretor de 1974 e no Programa de Ação Imediata de Transporte e Trânsito (PAITT), em 1978, que foram objeto de pesquisa da Prefeitura de São Luís para o planejamento do sistema de transporte coletivo. Nos Municípios da Ilha do Maranhão, entre 2006 e 2016, o crescimento demográfico foi acentuado (Quadro 1).

Quadro 1. Crescimento demográfico dos Municípios de São José de Ribamar, Paço do Lumiar, Raposa e São Luís. Fonte: elaborado pelo autor

\begin{tabular}{|l|c|c|c|c|c|}
\hline \multirow{2}{*}{ Ano } & \multicolumn{5}{|c|}{ Município } \\
\cline { 2 - 6 } & São Luís & São José de Ribamar & Raposa & Paço do Lumiar & Total \\
\hline 2006 & 998.335 & 134.593 & 21.347 & 101.554 & 1.255 .829 \\
\hline 2007 & 957.515 & 131.379 & 24.201 & 98.175 & 1.211 .270 \\
\hline 2008 & 986.826 & 135.821 & 25.042 & 101.452 & 1.249 .141 \\
\hline 2009 & 997.098 & 139.473 & 25.837 & 103.958 & 1.266 .366 \\
\hline 2010 & 1.014 .837 & 163.045 & 26.327 & 105.121 & 1.309 .330 \\
\hline 2011 & 1.027 .429 & 165.418 & 27.036 & 107.764 & 1.327 .647 \\
\hline 2012 & 1.039 .610 & 167.714 & 27.723 & 110.321 & 1.345 .368 \\
\hline 2013 & 1.053 .922 & 170.423 & 28.543 & 113.378 & 1.366 .266 \\
\hline 2014 & 1.064 .197 & 172.402 & 29.167 & 115.693 & 1.381 .459 \\
\hline 2015 & 1.073 .893 & 174.267 & 29.755 & 117.877 & 1.395 .792 \\
\hline 2016 & 1.082 .935 & 176.008 & 30.304 & 119.915 & 1.409 .162 \\
\hline
\end{tabular}


A infraestrutura, entre 2006 e 2016, não acompanhou o crescimento urbano acelerado, e o fluxo crescente de veículos aumentou consideravelmente em São Luís, face a implantação de equipamentos urbanos particulares (Figura 4).

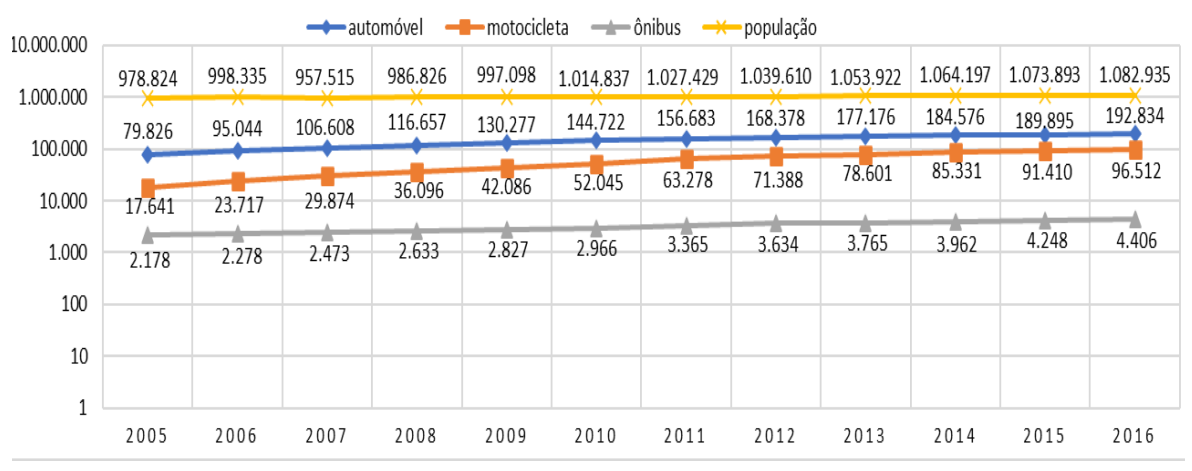

Figura 4. Gráfico logarítmico comparativo entre a frota de automóveis, motocicletas, ônibus e população no município de São Luís entre 2005 e 2016. Fonte: elaborado pelo autor

A frota de automóveis em São Luís, entre 2005 e 2016, cresceu 141\%, enquanto para motocicletas cresceu $447 \%$ e ônibus $102 \%$, no mesmo período. Embora o crescimento do ônibus seja maior, a sua frota permanece menor em relação ao automóvel e a motocicleta. Isto é consequência do não investimento em corredores exclusivos para transporte público (Cocco, 2011a).

O transporte público é prejudicado quando não são providas as infraestruturas necessárias para atender o usuário com melhor qualidade. Os buracos em ruas e avenidas e ondulações no asfalto pressionam a mudança de rotas de ônibus. A exemplo, já ocorreram alterações das rotas de linhas T073 - Tibiri; A671 - Tibiri; A341 - Residencial Amendoeiras/Santo Antônio (Figura 5) por causa dos buracos na via e prejuízo na manutenção de peças e equipamentos dos ônibus que ampliaram o tempo de viagem e resultaram em congestionamentos em outras vias.

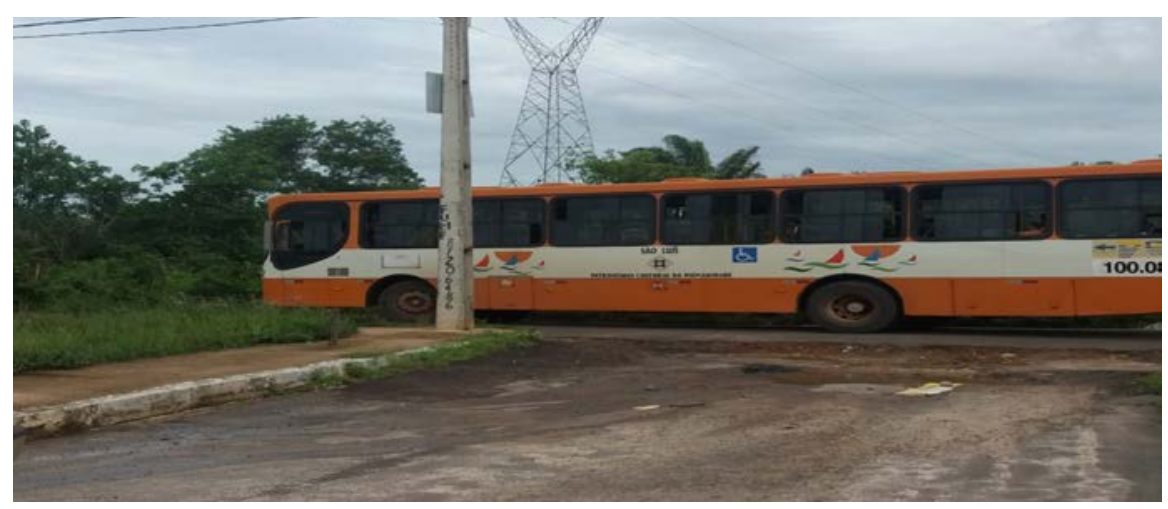

Figura 5. Ônibus passando ao lado do buraco no Residencial Santo Antônio. Fonte: elaborado pelo autor.

Após a construção do Residencial Amendoeiras e do Santo Antônio, nas proximidades do Bairro Maracanã, foi implantada uma linha de ônibus e esta enfrentou problemas com as péssimas condições da infraestrutura viária.Com muitos buracos e ausência de manutenção do asfalto após o período chuvoso, o Consórcio Central foi obrigado a mudar a rota da linha de ônibus, priorizando o arruamento com menos problemas de estrutura. 
Em São José de Ribamar, a "dispersão urbana" promoveu exclusão social nos bairros Jardim Tropical, Mata, Res. Nova Terra e Vila Kiola, conforme a Figura 6.

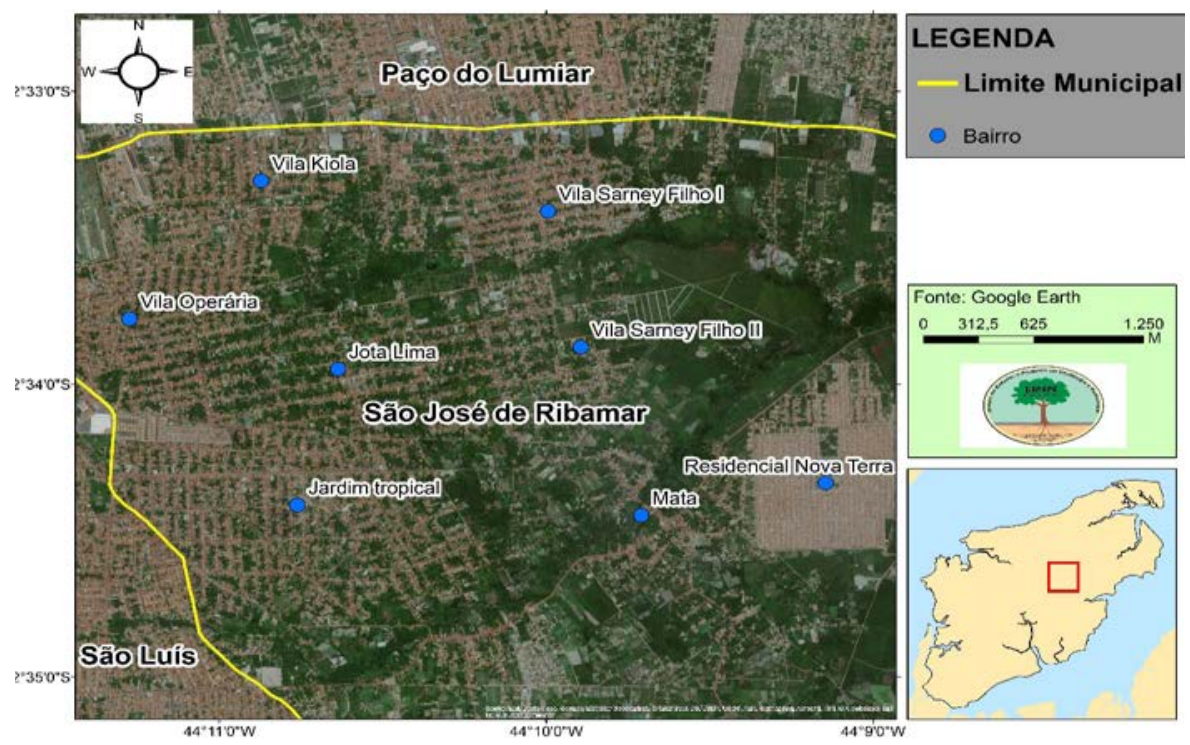

Figura 6. Bairros que compõem o município de São José de Ribamar - MA. Fonte: elaborado pelos autores.

A implantação desses bairros não acompanhou as infraestruturas e a oferta de equipamentos urbanos essenciais (escola, creche, unidade básica de saúde, escolas particulares). Por isso, o percurso do usuário para o trabalho, compras e lazer torna-se maior. A figura 7 apresenta a complexidade dos deslocamentos de passageiros nos municípios da Ilha do Maranhão.

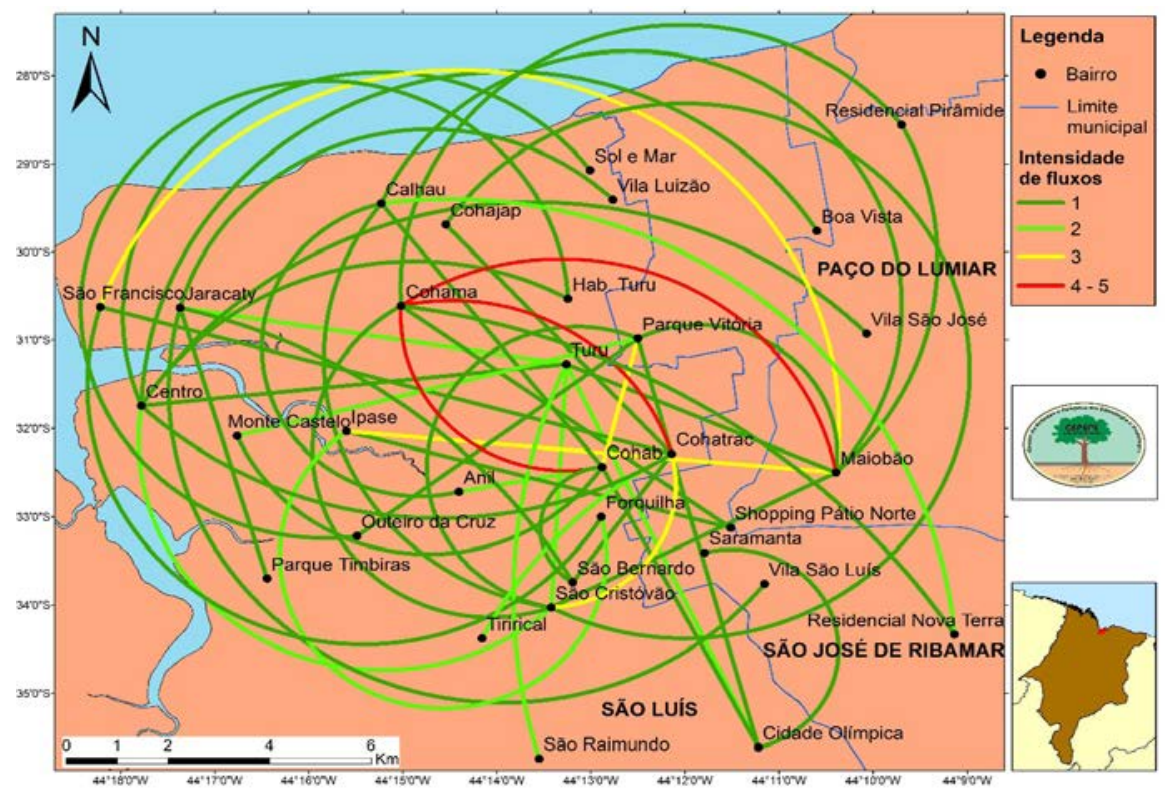

Figura 7. Fluxo de passageiros do sistema de transporte público no Terminal Cohab, São Luís-MA. Fonte: elaborado pelo autor.

A Figura 7 demonstra a presença de uma quantidade expressiva de destinos para os fluxos de transporte público em São Luís. Expressa também a complexidade de destinos 
no espaço insular da Região Metropolitana da Grande São Luís, inclusive vários centros regionais ou subcentros em que não há apenas uma única centralidade.

Embora haja grande fluxo de passageiros em direção ao Centro da cidade de São Luís, há outros destinos de viagem que tem uma quantidade significativa de passageiros (Figura 8). O quadro 2 mostra as principais características dos bairros

\section{- Maracană \\ - Anjo da Guarda \\ Monte Castelo \\ - BR-135 \\ E Coroadinho \\ Enil \\ Angelim \\ - Renascença \\ - Janaína \\ Cohama \\ - Turu \\ n Olho D'água \\ - Cohatrac \\ - Cidade Operária \\ Ealhau \\ - Centro \\ - São Cristóvăo \\ - Cidade Olímpica}

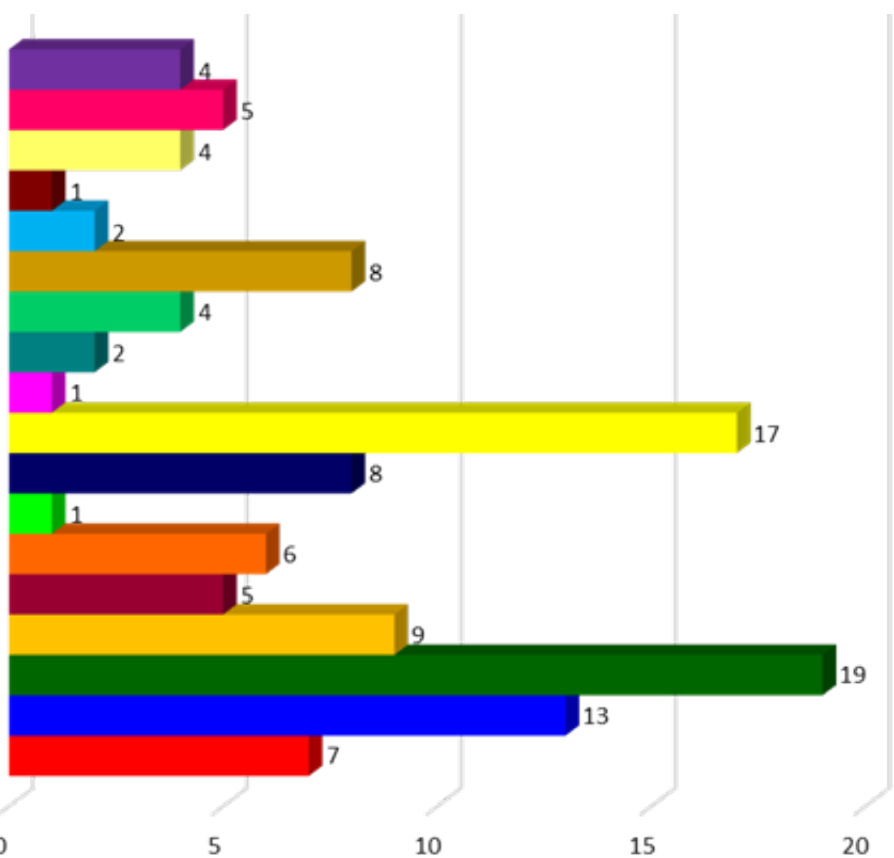

10

15

Figura 8. Principais destinos dos fluxos de transporte coletivo em São Luís/MA, em números absolutos. Fonte: elaborado pelo autor.

Quadro 12. Características dos bairros que compõem a llha do Maranhão. Fonte: elaborado pelo autor.

\begin{tabular}{|c|c|c|}
\hline Município & Bairro & Características \\
\hline São Luís & Cohama & $\begin{array}{l}\text { Dispõe de restaurantes, buffets, pizzarias, confeitarias e pet shops. } \\
\text { Equipamentos urbanos voltados à “demanda solvável” (Corrêa, } \\
\text { 1989) e para uma “demanda bem específica” (Santos, 2004:45). }\end{array}$ \\
\hline São Luís & São Cristóvão & $\begin{array}{l}\text { É servido pela Av. Guajajaras (via principal). Possui lojas de } \\
\text { material e construção, de peças e acessórios para automóveis e } \\
\text { metalomecânicas. }\end{array}$ \\
\hline São Luís & Calhau & $\begin{array}{l}\text { Bairro nobre da cidade. Concentra serviços a atividades } \\
\text { especializadas (Santos, 2004). Entre elas estão as concessionárias } \\
\text { de veículos e de autopeças. Buffets, lojas, restaurantes, shoppings, } \\
\text { escolas particulares e prédios administrativos são de alto padrão. } \\
\text { Sede de órgãos públicos do Estado. }\end{array}$ \\
\hline São Luís & Cidade Olímpica & $\begin{array}{l}\text { Bairro muito populoso e de baixa renda. O principal emprego } \\
\text { é o comércio. Deslocam-se para o bairro Cidade Operária } \\
\text { para acessar a farmácia, lojas de roupas e calçados, UPA, } \\
\text { supermercados e escolas públicas. Os ônibus que partem do } \\
\text { referido bairro apresentam-se superlotados. Por isso as avenidas } \\
\text { da Cidade Operária }(163,203,101) \text { apresentam gargalos no } \\
\text { trânsito. }\end{array}$ \\
\hline São Luís & Anil & $\begin{array}{l}\text { Apresenta moderada atividade comercial. Há faculdades e } \\
\text { escolas particulares. Servido pela via principal (Av. Casemiro } \\
\text { Júnior), apresenta uma via de maior fluxo e com gargalo no } \\
\text { cruzamento da Av. Santos Dumont. É destino de muitas linhas } \\
\text { troncais em direção ao centro da cidade. }\end{array}$ \\
\hline
\end{tabular}




\begin{tabular}{|l|l|l|}
\hline & & $\begin{array}{l}\text { É atendido pela Av. São Luís Rei de França (via principal). } \\
\text { Apresenta moderada atividade comercial. Há faculdades, escolas } \\
\text { particulares, condomínios, residenciais e um shopping (Rio Anil). } \\
\text { O gargalo de trânsito da via principal localiza-se na rotatória do } \\
\text { Elevado da Cohab, cruzamento da Av. Jerônimo de Albuquerque } \\
\text { (via de maior fluxo). }\end{array}$ \\
\hline
\end{tabular}

Nos bairros supracitados de São Luís, há a segregação social e as áreas especializadas (CORRÊA, 1989). Exemplo disso é que, em São Luís, localizam-se no Bairro Calhau o Golden Shopping Calhau, o Blue Tree Towers Hotel e o Restaurante Cabana do Sol (Figura 9).

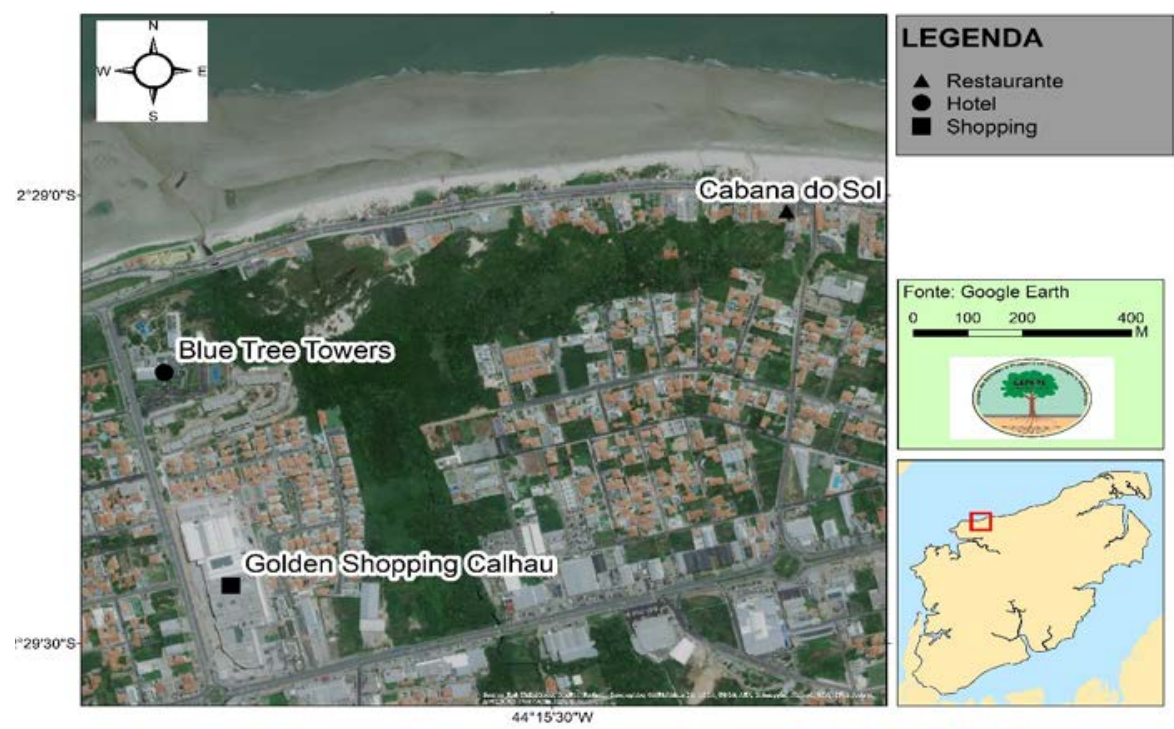

Figura 9. Equipamentos urbanos no Bairro Calhau, em São Luís-MA. Fonte: elaborado pelo autor.

A implantação de Shopping Centers acompanhou impactos pelo aumento da frota de automóveis e do crescimento urbano (Figura 10), promovendo gargalos nas principais vias de São Luís. A exemplo, os shoppings São Luís e Shopping da Ilha (Figura 10).

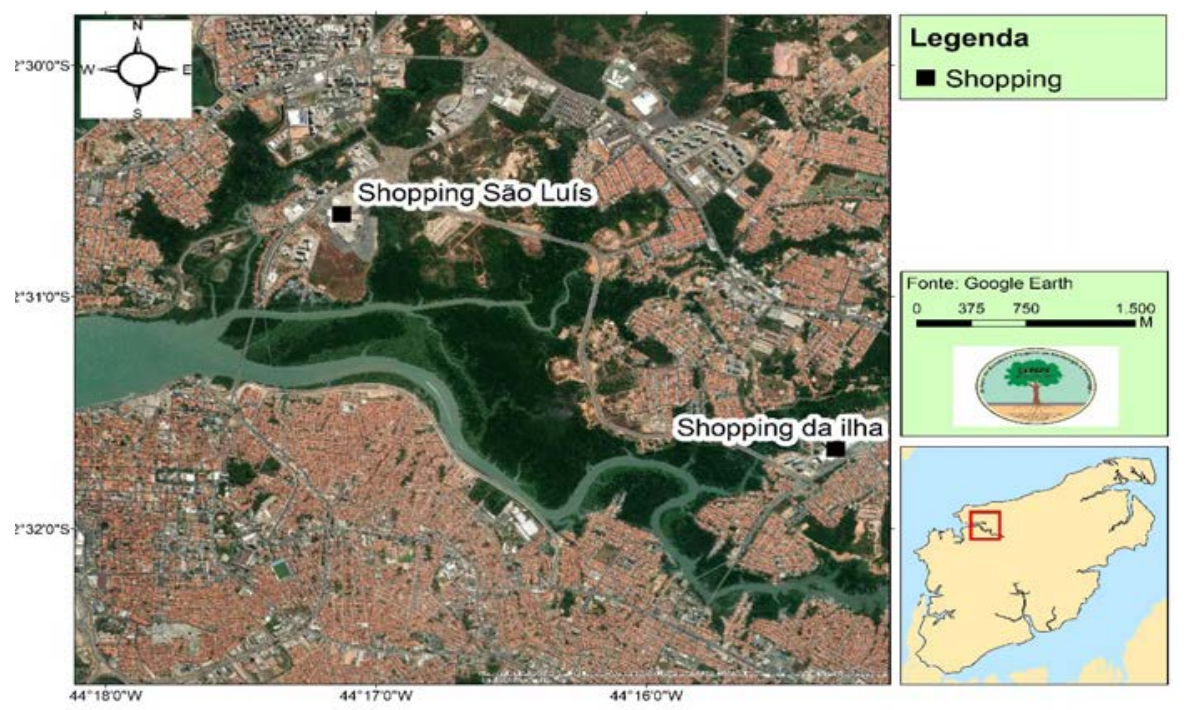

Figura 10. Localização do Shopping São Luís e Shopping da Ilha, em São Luís-MA. Fonte: elaborado pelo autor. 
Esses empreendimentos atraem muitas oportunidades de consumo e emprego para a sociedade ludovicense, pois com eles foram inauguradas lojas de departamento, mais praças de alimentação, cinemas, bomboniere, áreas de lazer, entre outros. Estes fortalecerem muito a atividade comercial da Ilha do Maranhão como um todo.

Enquanto que nos bairros de população de baixa renda, tais como Janaína, Cidade Olímpica, Santa Clara, Geniparana, Nice Lobão e Residencial Tiradentes a única Unidade de Pronto Atendimento adjacente localiza-se no Bairro Cidade Operária. É também o bairro mais próximo que oferta comércio de calçados, roupas, frutas, farmácias e feiras (Figura 11).

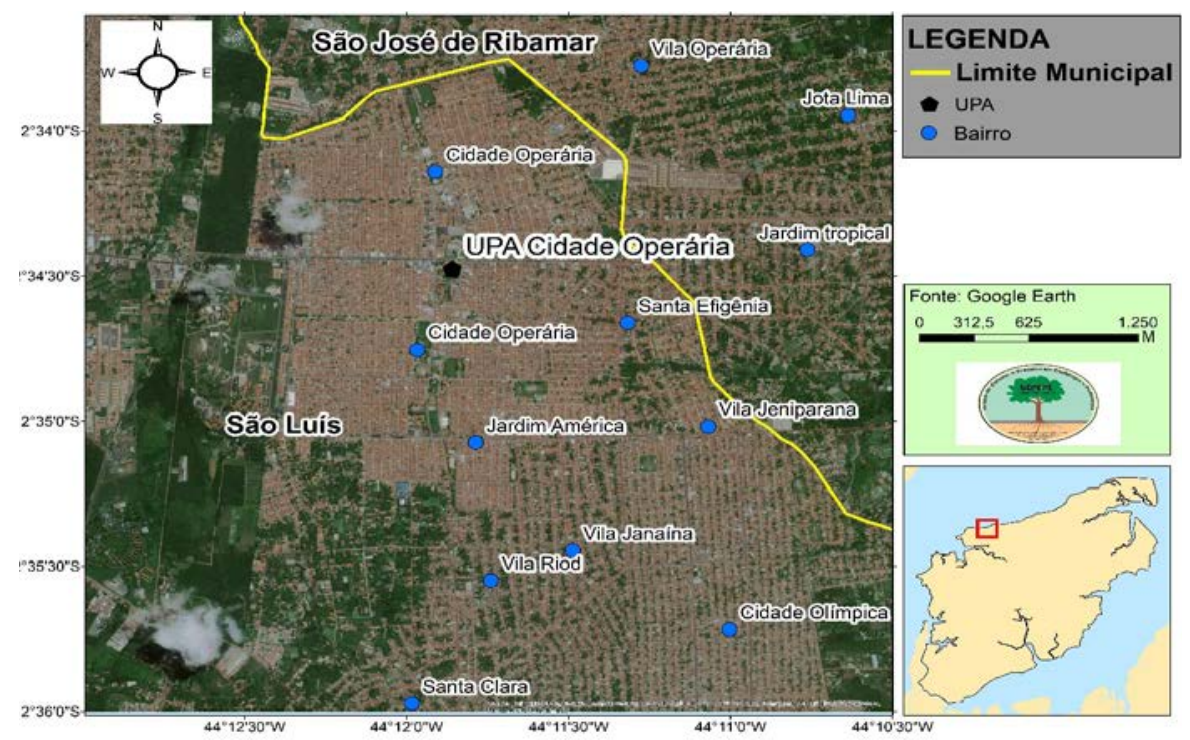

Figura 11. Localização da UPA Cidade Operária, em São Luís-MA. Fonte: elaborado pelo autor.

A população de baixa renda em São Luís e outros municípios da região metropolitana mora em bairros distantes do Centro e dos bairros que abrigam a população mais segregada. $\mathrm{O}$ maior tempo de espera nas paradas, superlotação, desconforto e pouca oferta de transporte coletivo para os bairros São Marcos, Ponta D’areia, Calhau, Cohama, Barramar, Renascença e Av. Litorânea (Figura 12) faz com que hajam dificuldades para chegar ao trabalho nas áreas que apresentam maior oferta de emprego e de equipamentos urbanos comerciais.

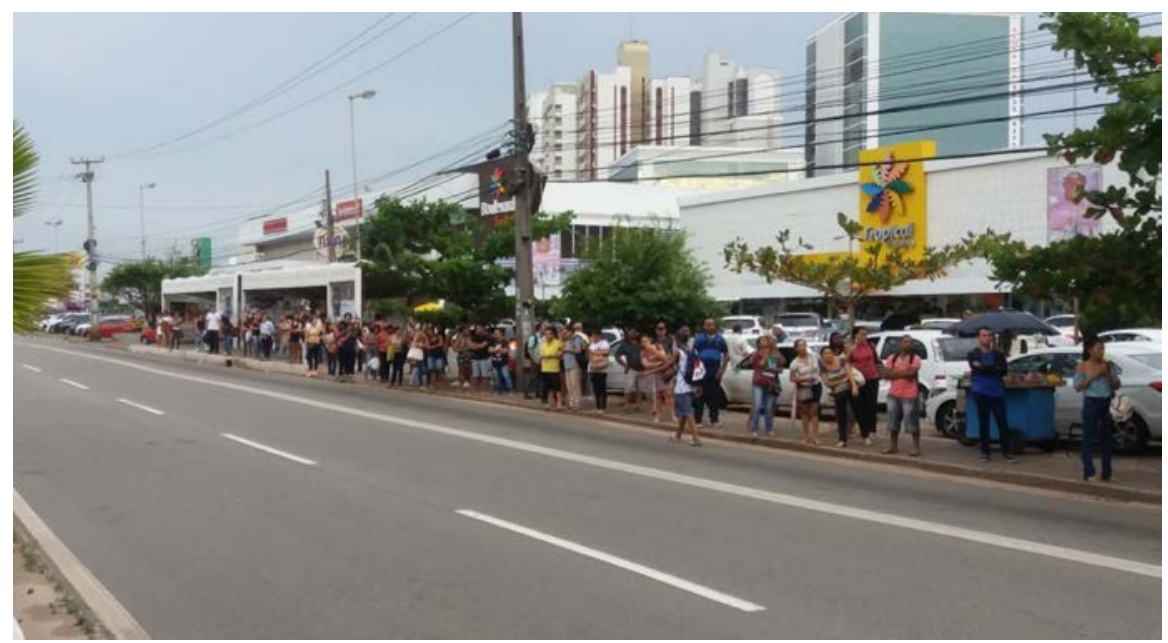

Figura 12. Concentração de usuários de transporte público no Bairro Renascença devido à grande oferta de trabalho, causando maior tempo de espera do ônibus às 17h. Fonte: Elaborado pelo autor. 
O aumento no número de moradias das camadas de baixa renda, impulsionadas pela expansão urbana dispersa, não acompanha a oferta de equipamentos urbanos nos bairros. Isso evidencia o tempo de deslocamento como reflexo das lutas de classe no ambiente construído, em que a população luta por melhores condições de habitação, trabalho, transportes, saúde e qualidade de vida. Ao passo que os bairros vão sendo estruturados e o custo de vida aumenta, a população de baixa renda acaba sendo forçada a ocupar bairros mais distantes.

São Luís já apresenta os reflexos de crescimento demográfico acentuado e a urbanização seletiva que não acompanha projetos de reestruturação econômica e preocupase mais em mitigar problemas e resolver urgências (Pedrão, 2005). Essa urbanização seletiva na Região Metropolitana da Grande São Luís é causada pelas oportunidades de investimentos econômicos multinacionais que não priorizam o desenvolvimento, articulado pela redistribuição de renda local, mas sim o crescimento econômico. Isso a torna em regiões polarizadoras (Santos, 2004), chamadas de polos geradores de tráfego.

A implantação de equipamentos urbanos seletivos, destinados à população de alta renda, impõem preços elevados em relação à maioria da renda da população e não são consumidos em todas as camadas da sociedade, conectada a certo público (Santos, 2004).

Os demais equipamentos urbanos, por outro lado, não oferecem acessibilidade para a maioria da população. O consumo é seletivo (Nadalin, 2011 e Santos, 2004). O exemplo disso é a loja de doce "Cantinho Doce". Os preços de bombons, confeitaria, artigos de festa e outros são muito altos e quem desfruta são as camadas de alta renda, graças ao incentivo do marketing e da propaganda. A loja de bombons "Bombom e Companhia" oferece doces, salgadinhos e bombons com preços mais acessíveis a maioria da população, inclusive para os comerciários na revenda - ela não utiliza propaganda.

As políticas de transporte e mobilidade urbana devem priorizar a melhoria da acessibilidade para as pessoas de baixa renda, idosos e deficientes, pois a mobilidade condiciona a oportunidades (Pereira, 2018). Este fato também deve ser aplicado no acesso ao turismo e a megaeventos, a exemplo na Ilha do Maranhão temos a Via Sacra, Círio de Nazaré, Lava-Pratos, Carnaval e Ano Novo.

Outros problemas são a ausência de oferta de equipamentos urbanos nos municípios de Paço do Lumiar, São José de Ribamar e Raposa, tais como hospitais públicos, faculdades, cursos técnicos e profissionalizantes, centro de especialidades médicas e clínicas particulares.

Outra atividade comercial importante em expansão nos municípios da Ilha do Maranhão é a rede de supermercados atacadista e varejista do "Grupo Mateus" (Mix Atacarejo) e do "Assaí Atacadista" (Figuras 13 e 14). 


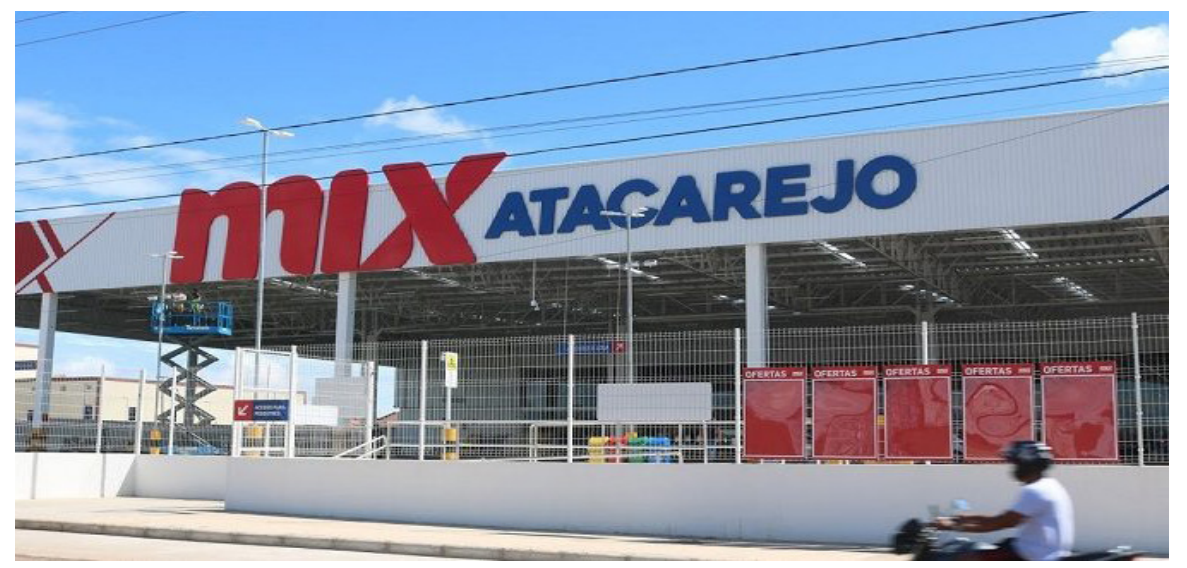

Figura 13. Mix Atacarejo no Bairro Olho D’água, em São Luís-MA. Fonte: Jornal Folha do Maranhão.

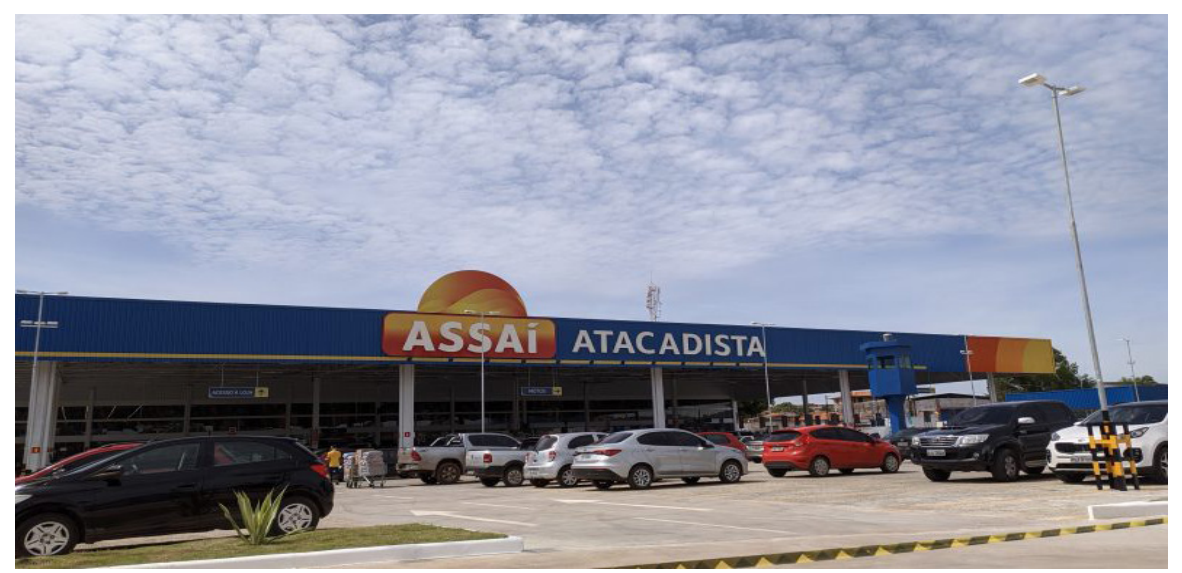

Figura 14. Assaí Atacadista no Bairro São Bernardo, em São Luís-MA. Fonte: O Maranhense.

Sobre o "Mix Atacarejo", foram implantados em bairros de grande densidade demográfica tais como Cidade Operária, Maiobão, Vinhais, Olho D’água, São Cristóvão, João Paulo. É o local onde a maioria da população desloca-se para fazer compras, configurando-se como polos geradores de tráfego. Enquanto isso, o "Assaí Atacadista" teve a primeira loja na Avenida Guajajaras inaugurada e a segunda loja está em construção no Bairro Turu. Esse é também o destino da maioria da população, visto que os preços são competitivos ao "Mix Atacarejo". Por esse motivo, O "Mix Atacarejo" está construindo mais uma loja no Bairro Planalto Pingão.

Nesses locais, foram abertas muitas oportunidades de mão de obra especializada, tais como confeitaria, cozinheiro, operador de máquinas, operador de caixa, analista administrativo, recursos humanos, fiscal, anunciante, açougueiro, marketing e faturista. Houveram também mais oportunidades para realizar compras, visto que o supermercado oferta preços mais acessíveis ao consumidor e produtos de alta qualidade, com investimentos em armazenamento, estratégias de implantação em centros distribuidores e logística de transporte, aliado com o agronegócio.

A expansão urbana dispersa, aprofundada pela ausência de instituições públicas e particulares, promoveu o incremento da distância do tempo de mobilidade dos cidadãos, principalmente os deslocamentos casa-trabalho (Miralles-Guasch, 2013). Os bairros Tibiri, Residencial Ivaldo Rodrigues, Residencial Marcelo Dino, Alto do Turu, Araçagi e Santana foram construídos em função da implantação de loteamentos em 2014, mas não houve uma provisão de infraestrutura e serviços urbanos essenciais. Há problemas 
de descontinuidades territoriais, rupturas nas vias urbanas e a ausência de infraestruturas básicas (saneamento, galerias de águas pluviais, rede de esgoto, escolas, creches, supermercados, etc.). Associados ao problema mencionado anteriormente, surgem novos e graves obstáculos, como, por exemplo, a impossibilidade de implantação de linhas de ônibus para atender melhor os usuários que residem nos referidos bairros. $\mathrm{O}$ custo de circulação do transporte público é acrescido pelos vazios intersticiais, muitas vezes fragmentados territorialmente, onde parte significativa dos loteamentos já foi urbanizada, demandando da provisão de transporte público.

Os bairros Aracagi, Alphaville, Vila Rio São João e Miritiua são bairros que estão em fase de expansão urbana dispersa e de valorização imobiliária. Já possuem muitas casas, condomínios particulares e apartamentos de alto padrão (e outros em construção). Esses bairros ainda não têm supermercados de alto padrão para atender as demandas crescentes, obrigando os moradores a deslocarem-se mais, nos bairros Turu e Olho D'água, para fazerem compras. Há comércios nesses bairros, mas não com preços acessíveis, inclusive esses comércios compram na cadeia de supermercados para a revenda.

A realidade torna urgente o investimento em políticas públicas de mobilidade urbana, uma vez que possuem uma população superior a 1,2 milhões de habitantes e não possuem um plano de transporte e mobilidade urbana conforme previsto no Estatuto da Cidade e na Política de Mobilidade Urbana. A necessidade de construção desses novos corredores é urgente e justifica-se pela estagnação do Índice de Passageiros por Quilômetro (IPK) dos terminais de integração do sistema de transporte público (Quadro 3).

Quadro 3. Indicadores de produtividade de serviço do sistema de transporte público coletivo de São Luís entre 2012-2017. Fonte: SMTT, 2015.

\begin{tabular}{|l|c|c|c|c|}
\hline Ano & $\begin{array}{c}\text { Passageiros } \\
\text { Transportados }\end{array}$ & $\begin{array}{c}\text { Quilometragem } \\
\text { Percorrida }\end{array}$ & IPK & Viagens Realizadas \\
\hline 2012 & 10.459 .216 & $4.805 .966,7$ & 2,17 & 172.800 \\
\hline 2013 & 13.718 .571 & $6.294 .930,9$ & 2,17 & 201.873 \\
\hline 2014 & 7.858 .943 & $3.162 .222,4$ & 2,49 & 90.393 \\
\hline 2015 & 10.541 .489 & 4.635 .375 .7 & 2,27 & 135.933 \\
\hline 2016 & 10.396 .251 & $4.602 .782,8$ & 2,26 & 134.304 \\
\hline 2017 & 13.705 .317 & $6.078 .292,9$ & 2,25 & 196.685 \\
\hline $\begin{array}{l}\text { Crescimento } \\
\text { acumulado }\end{array}$ & $31 \%$ & $26 \%$ & $4 \%$ & $14 \%$ \\
\hline $\begin{array}{l}\text { Taxa anual de } \\
\text { crescimento }\end{array}$ & $32 \%$ & $26 \%$ & $3,7 \%$ & $13,8 \%$ \\
\hline
\end{tabular}

Embora haja aumento do número de viagens, dos passageiros transportados e o IPK constante entre os anos 2012 e 2013, houve um aumento considerável deste índice no ano de 2014, com redução das viagens realizadas, de passageiros transportados e da quilometragem percorrida. Ocorreu um decréscimo da qualidade do transporte público e a migração para o automóvel, o que incorre em aumento de usuários de transporte individual.

Outro fator que contribui para o aumento do IPK no período de 2014 foi:1) a decisão das empresas de ônibus pela alteração de linhas troncais semiurbanas (ligam um município ao outro município, intermunicipais) em que as linhas T975 - Iguaíba/ Term. Cohab/Term. Praia Grande; T989 - Mojó/Term. Praia Grande; T977 - Residencial Pirâmide/João Paulo; e T978 - Raposa/São Francisco em alimentadoras (de bairro até o terminal de integração), para reduzir a quilometragem percorrida, já 
que houve sobreposição de itinerários e não atingiram a quantidade de passageiros suficiente, logo combustível teve seu custo reduzido; 2) criação de linhas alimentadoras do município de São Luís e intermunicipais para atender o usuário de bairros periféricos, tais como A313 - Tamancão; A685 - Residencial Nestor; A688 - Residencial Tiradentes; A316 - Vila São Luís; A327 - Residencial Piancó; A981 - Residencial Turiúba; A336 - Maracanã/Term. Distrito; A334 - Estiva/Term. Distrito, entre outras; implantação de linhas T408 - Vila Nova/Calhau e T320 - Residencial Paraíso/Bandeira Tribuzzi pela unificação de duas linhas em uma; 3 ) as empresas de ônibus não cumpriram os horários de viagem, causando demora no tempo de espera e superlotação, principalmente das linhas troncais em direção ao centro da cidade, área em que muitas linhas alimentadoras foram criadas e levaram os usuários até os terminais de integração.

Essas estratégias dos empresários levaram à perda de produtividade do transporte público e aumento do IPK, o que causou a migração do usuário para o transporte alternativo. Percebe-se também que embora haja aumento relativo do número de viagens realizadas, dos passageiros transportados e da quilometragem percorrida pelas novas linhas, o IPK manteve-se relativamente constante e o mesmo não foi compensado pelo aumento das viagens e a quilometragem, causando maiores custos do sistema de transporte público.

A ocupação dos bairros de baixa densidade demográfica aumenta o custo de serviço de transporte público (Vasconcellos, 2000). Por isso, as concessionárias fizeram alterações em trajetos de algumas linhas para otimizar o tempo de viagem e redução de custos de combustível em relação ao número de passageiros transportados em cada trecho.

Nas áreas rurais recém incorporadas ao perímetro urbano, a dispersão urbana e a construção de grandes conjuntos habitacionais do Programa Minha Casa, Minha Vida formam vazios intersticiais e atraem demandas por transporte público, sendo que a atual oferta não atende todos os usuários. No caso de Natal/RN, a política habitacional promoveu segregação social aos pobres. As periferias tornaram-se distantes e desprovidas de equipamentos urbanos essenciais. Esta política aumentou as distâncias ao trabalho, escola, compras e lazer (Morais, 2010).

Em relação ao uso e ocupação do solo, os vazios intersticiais são uma problemática evidente. Todo serviço que for implantado tem seus custos aumentados, porque a extensão é alta e não tem consumidor para compartilhar e custear toda a extensão do serviço, como bem exemplifica o abastecimento de água, energia e esgoto.

Os fluxos concentram-se nos terminais rodoviários, pelos ônibus intermunicipais rodoviários provenientes dos municípios de Bacabeira, Rosário, Morros, Santa Rita, Presidente Juscelino, Icatu e Cachoeira Grande; nos terminais de integração, pelos ônibus intermunicipais semiurbanos; nos corredores viários; e rodovias. Este é o caso da BR-135 entre São Luís e Bacabeira; MA-201 entre São Luís, Paço do Lumiar e São José de Ribamar; MA-202, MA-203 entre São Luís e Raposa, Avenida Guajajaras, Avenida Jerônimo de Albuquerque, Avenida dos Franceses e Avenida dos Portugueses em São Luís. Nestas vias, efetuam-se a integração do sistema de transporte "intraurbano" e a integração entre o sistema semiurbano de passageiros, mas há carência de uma melhor articulação entre esses sistemas. A desarticulação dos horários para integração prejudica os usuários que se deslocam a partir de longas distâncias. Um dos aspectos que deve ser melhorado reside nas intervenções viárias e no reordenamento de tráfego, com mudanças em sua geometria. 


\section{Conclusão}

A pesquisa permitiu concluir que os principais problemas de mobilidade nos municípios da Ilha do Maranhão estão relacionados às demandas dos usuários do transporte coletivo, que saem de zonas periféricas e dirigem-se às zonas mais centrais para acessarem seus postos de trabalho, escolas, faculdades, comércios e opções de lazer.

É válido ressaltar que grande parte desses deslocamentos ocorre porque a localização dos serviços não acompanha as demandas da população e, quase sempre, estão concentrados em áreas tradicionalmente mais centrais. Os bairros periféricos enfrentam um crescimento urbano espraiado e a quantidade de equipamentos urbanos não acompanha esse processo. O elevado tempo de deslocamento via transporte público reduz a sua qualidade e obriga grande parte da população a adquirir-se e locomover-se por meio de veículo de passeio, fato que resulta em congestionamentos e reduz a mobilidade de todos os usuários das vias, as quais não possuem dimensões e condições adequadas.

Embora tenha ocorrido um aumento do IPK e da efetivação da licitação do transporte público em São Luís, as concessionárias seriam obrigadas a elaborarem suas estratégias logísticas para a lucratividade de linhas, seja por exclusão, fusão ou alteração, pois o edital da prefeitura de São Luís exige isso. Por um lado, exclui uma linha de ônibus, causando para o usuário a menor oferta e, por outro lado, a racionalização e otimização do sistema de transporte público para o acompanhamento da demanda real para tornar o transporte público mais eficiente e valorizado.

Esse aumento de IPK pode ser explicado pela migração de muitos usuários do transporte individual para o transporte coletivo, já que existem ônibus climatizados e que andam cheios, mas também pela readequação logística das próprias companhias, que reduzem horários e linhas gradativamente e assim solicita a própria Secretaria de Trânsito e Transporte para aprovar seus processos de exclusão, quando observam que sua lucratividade está ameaçada. 


\section{Q Bibliografía}

"Balassiano, R. (1996). Transporte por vans - o que considerar no processo de regulamentação? Revista Transportes, 1, 87-105.

» Barat, J. (2001). Transporte e mobilidade em São Paulo. Revista dos transportes públicos - ANTP, São Paulo, 93, 51-74.

"Cabral, M. do S. C. (1992). Caminhos do gado: conquista e ocupação do sul do maranhão; prefácio de Manoel Correia de Andrade. - São Luís: SIOGE.

»Chatel, C., Sposito, M. E. B. (2015). Forma e dispersão urbanas no brasil: fatos e hipóteses. Primeiros resultados do banco de dados brasipolis. Revista Cidades, Rio Claro - SP, 12 (21), 108-152.

»Cheptulin, A. (1982). A dialética materialista:categorias e leis da dialética. São Paulo: Alfa-Ômega.

" Cocco, R. G. (2011a). Interações espaciais e sistemas de transporte público: uma abordagem para Bauru, Marília e Presidente Prudente. Dissertação (mestrado) - Universidade Estadual Paulista, Faculdade de Ciências e Tecnologia. Presidente Prudente, São Paulo.

"Cocco, R. G. (2013). Interações espaciais e transporte público: proposições para a Grande Florianópolis/SC. In: $14^{\circ}$ Encontro de geógrafos da América Latina, Lima, Peru.

"Cocco, R.; Silveira, M. (2011). Interações espaciais, transporte público e estruturação do espaço urbano. Revista Brasileira de Estudos Urbanos e Regionais,12(1), 63-81. Local de publicação. Recife/PE. 12.

"Cocco, R. G. (2011b) Transporte público coletivo: acessibilidade e crise nas cidades do interior paulista. In: SILVEIRA, Márcio Rogério. Circulação, transportes e logística: diferentes perspectivas. (pp. 553-579) São Paulo: Outras Expressões.

"Corrêa, R. L. (1989). A rede urbana. São Paulo: Editora Ática.

" Corrêa, R. L. (2006). Interações Espaciais. In: Castro, I. E. de. Gomes, P. C. da C. Corrêa, R. L. (Org.). Explorações geográficas: percursos no fim do século. (pp. 279-314). Rio de Janeiro: Bertrand Brasil..

"Cunha, R. C. (2015). Ocupação e o desenvolvimento das duas formações socioespaciais do maranhão. Revista CaderNAU - Cadernos do Núcleo de Análises Urbanas, Rio Grande/RS, 8(1), 133-152.

» Farias Filho, M. S. (2004). Atuação das elites regionais na configuração e "modernização" do espaço urbano de São Luís nas décadas de 1920-1930: a administração municipal de Octacílio Saboya Ribeiro. Monografia de Graduação em Geografia. Universidade Estadual do Maranhão.

"Ferreira, A. J. de A. (2014). A produção do espaço urbano em São Luís do Maranhão: passado e presente; há futuro? - São Luís: EDUFMA.

» Karakayaci, Z. (2016). The concept of urban sprawl and its causes. Journal of International Social Research. 9. 815-815.

" Maricato, E. (2012). As ideias fora do lugar e o lugar fora das ideias. In: Arantes, O., Vainer, C. e Maricato, E. A cidade do pensamento único: desmanchando consensos. - Petrópolis, RJ: Vozes. 
» Maricato, E. (2020). Metrópole, legislação e desigualdade. Estud. av., São Paulo17 (48),151-166,.

" Marquet, O.; Miralles-Guash, C. (2016). The The Walkable city and the importance of the proximity environments for Barcelona's everyday mobility. Cities, 42, 258-266.

» Miralles-Guasch, C. E Sardà, O. M. (2013). Dinámicas de proximidad en ciudades multifuncionales. Cytet Ciudad y Territorio, Estudios Territoriales,46(177), 503-512.

» Miralles-Guasch, C., Melo, M. M.; Marquet, O. (2015). A gender analysis of everyday mobility in urban and rural territories: from challenges to sustainability. Gender, PlaceECulture, 23(3), 398-417.

" Morais, T. M. da C. (2010). Espaços de pobreza e mobilidade urbana: os deslocamentos da população de baixa renda em Natal/RN. Dissertação (Mestrado) - Universidade Federal do Rio Grande do Norte. Centro de Tecnologia. Departamento de Arquitetura. - Natal, RN.

» Mortari, R. e Euzébio, G. L. (2009). O custo do caos. In: Instituto Econômico de Pesquisa Aplicada. Revista Desafios do desenvolvimento:o custo do transporte individual 6,53.

» Nadalin, V.anessa G. (2011). Economia urbana e mercados de habitação. In: CRUZ, Bruno de Oliveira et al (org.). Economia regional e urbana: teorias e métodos com ênfase no Brasil. (pp. 221-258) Brasília: IPEA, 2011 (221-258).

»Pedrão, F. (2005). Fermentos econômicos de uma urbanização contraditória. Revista de Desenvolvimento Econômico - RDE, Salvador/BA, 7(12), 5-13.

"Peixoto, A. P. M. (2011). Vacância residencial na Região Metropolitana de Belo Horizonte: mobilização do estoque vago para a promoção de habitação de interesse social. Dissertação (Mestrado) -Faculdade de Arquitetura e Urbanismo, Universidade Federal de Minas Gerais. Belo Horizonte.

»Pereira, R. H. M. (2018). Transport legacy of mega-events and the redistribution of accessibility to urban destinations. Cities, 81, 2018, 45-60.

"Santos, M. (2009). A urbanização brasileira. $-5^{\mathrm{a}}$ ed., $2^{\mathrm{a}}$ reimpressão - São Paulo: Editora da Universidade de São Paulo.

"Santos, M. (2004). O espaço dividido: os dois circuitos da economia urbana dos países subdesenvolvidos. $-2^{\underline{a}}$ ed.- São Paulo: Editora da Universidade de São Paulo.

» Santos, M. (1977). Sociedade e Espaço: a formação social como teoria e como método. In: Boletim Paulista de Geografia, São Paulo 54, 81-99.

"São Luís. (2020). Prefeitura de São Luís. Disponível em: <http://www.saoluis. ma.gov.br/>. Acesso em: 7 jun. 2020.

» Siqueira, J. G. C. (2018). Interações espaciais e condições do transporte coletivo nos municípios da llha do Maranhão. Dissertação (Mestrado) - Programa de Pós-Graduação em Desenvolvimento Socioespacial e Regional, Universidade Estadual do Maranhão.

»Sposito, M. E. B. (2010). A questão cidade-campo: perspectivas a partir da cidade. In: Sposito, Maria Encarnação Beltrão; WHITACKER, Arthur Magon (org.). Cidade e campo: relações e contradições entre urbano e rural. - 2.ed. São Paulo: Expressão Popular, 111-130.

» Trovão, J. R. (2008). O processo de ocupação do território maranhense. - São Luís: IMESC. 
》Vasconcellos, E. A. (2000). Transporte urbano nos países em desenvolvimento: reflexões e propostas.- 3. Ed. - São Paulo: Annablume,.

"Villaça, F. (2001). O espaço intra-urbano no Brasil. 2. ed. São Paulo: Studio Nobel; FAPESP: Lincoln Institute.

\section{Marcelino Silva Farias Filho / marcelinobrasil@msn.com/marcelinobrasil@ gmail.com}

Professor do Departamento de Geociências e do Programa de Pós-Graduação em Geografia da Universidade Federal do Maranhão, doutor em Agronomia (Ciência do Solo) pela Universidade Estadual Paulista - UNESP, mestre em Agroecologia e licenciado em Geografia pela Universidade Estadual do Maranhão, bacharel em Geografia e licenciado em História pela Universidade Federal do Maranhão. É líder do Grupo de Estudos e Pesquisa em Edafologia e Pedologia - GEPEPE e tem experiência em cartografia e estudos dos solos, com ênfase em variabilidade dos atributos e classes dos solos e sua conservação.

\section{Juan Guilherme Costa Siqueira / juan_siqueira16@hotmail.com}

Possui Graduação em Geografia Bacharelado e Licenciatura pela Universidade Federal do Maranhão (UFMA). Mestrando do Programa de Pós-Graduação em Desenvolvimento Socioespacial e Regional da Universidade Estadual do Maranhão (UEMA). Tem experiência na Geografia, atuando nas áreas de Geografia urbana, Geografia dos transportes e Geografia econômica, com ênfase em estudos de transportes públicos, infraestruturas e circulação no espaço urbano. É membro do Grupo de Estudos e Pesquisas em Edafologia e Pedologia (GEPEPE). 